\title{
Reduction of air pollution as a basis for a healthy urban environment
}

\author{
Anna Lis * \\ Częstochowa University of Technology, Faculty of Civil Engineering 42-200 Czestochowa, Poland
}

\begin{abstract}
The WHO report shows that air in the majority of cities in the world is polluted to a large extent. Air pollution is one of the basic environmental causes of premature deaths in the world. The main source of air pollution in cities is the low emission associated with fuel combustion to generate heat for buildings heating, communication and industry. The existing buildings in Poland are characterized by high energy and, consequently, ecological potential. The aim is to estimate predicted energetic and ecological effects of activities that adapt existing residential buildings to the requirements for the thermal protection of buildings in Poland and presenting the possibility of using renewable energy sources. The energy demand for heating buildings at $60-70 \mathrm{kWh} /\left(\mathrm{m}^{2} \mathrm{rok}\right)$ has been adopted. The calculations show that as a result of this adjustment, the energy demand for heating in residential buildings may decrease by an average of around 67\% compared to 2011. Such actions will reduce the overall emissions of air pollution from households by reducing the energy requirement for heating apartments from about 30\% to about $67 \%$, depending on the type of pollutant.
\end{abstract}

\section{Introduction}

Pollutants introduced into the air as a result of low emissions accumulate around the place of their production and are, under unfavourable weather conditions, the cause of the formation of smog. The source of low emission is fuel combustion in order to generate heat for the needs of central heating and preparation of hot usable water especially in lowefficiency individual boiler, communication and industry. According to observations, low emissions are an important cause of poor air quality and a major factor in creating unfriendly environments especially in cities in Poland and in other countries. Harmful substances for humans, that increase the risk of cardiovascular and respiratory diseases or death are above all particulate matters PM10 and PM2.5, polycyclic aromatic hydrocarbons, e.g. benzo(a)pyrene, dioxins, sulphur dioxide, nitrogen oxides, carbon monoxide, carbon dioxide, as well as heavy metals [1,2].

Based on data from International Energy Agency and World Health Organization British company Eco Experts made the map of the most toxic country in the world [3]. Parameters adopted for the study are energy consumption per capita, carbon dioxide

\footnotetext{
* Corresponding author: alis@bud.pcz.pl
} 
emissions from fuel combustion per capita, air pollution, deaths attributable to air pollution per 100,00 capita and renewable energy production (Fig. 1).

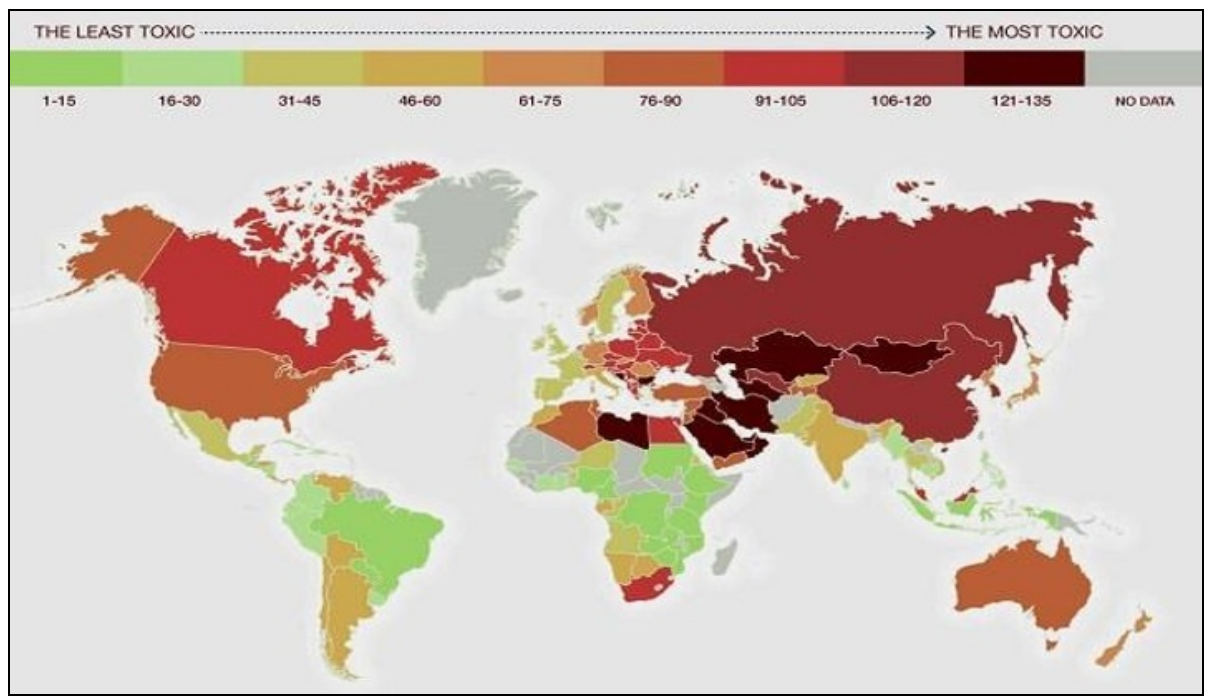

Fig. 1. The map of the most toxic country in the World [3].

In the report of United Nations Economic Commission for Europe suggest that air pollution is still the primary environmental cause of premature deaths in Europe and smog is indicated as the 11th cause of death in the world [4]. The latest WHO data presents air quality measurements from over 4,300 cities in 109 countries. Air pollution on average in $80 \%$ of countries in the world exceeds acceptable standards, including $97 \%$ in poor and medium-wealth countries, and $49 \%$ in wealthier countries [5]. The most polluted cities are in the Middle East, Southeast Asia, Africa and India but among the 50 most polluted PM2.5 cities of the Europe 36 are located in Poland (Fig. 2.).

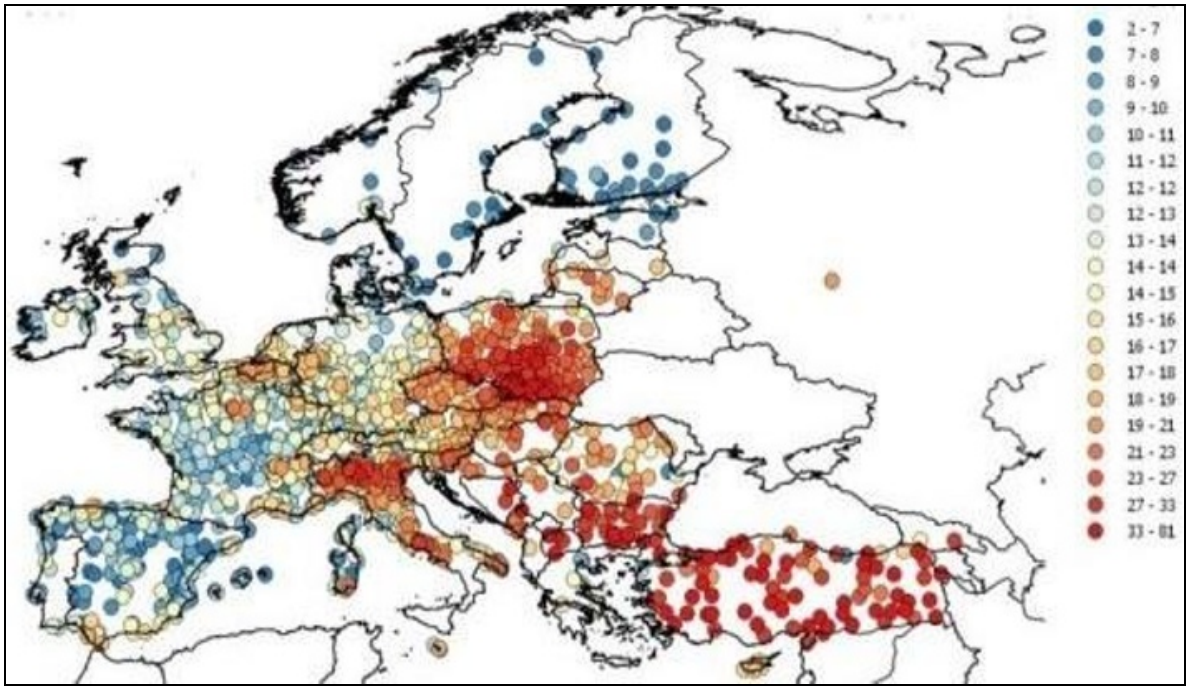

Fig. 2. PM2.5 air pollution concentration in Europe in $\mu \mathrm{g} / \mathrm{m}^{3}[5]$.

Information about the significant contamination of the area of Poland with particulate matter is also confirmed by the report of the European Environment Agency and Polish 
Inspectorate for Environmental Protection [6, 7]. The average annual concentration of benzo(a)pyrene exceeds the acceptable standards by $500-600 \%$. As air quality declines, the risk of stroke, heart disease, lung cancer, and chronic and acute respiratory diseases, including asthma, increases. Air pollution shortens the lives of Polish residents by more than 12 months [4] and causes the premature death of about 46,000 people in Poland every year [6]. This is 10 times more than in the case of road accidents [8].

Poor air quality in urban areas is particularly troublesome during the heating season. Low thermal insulation of a large number of currently used buildings is associated with large heat losses, which results in a significant consumption of energy carriers and high levels of pollutant emissions to the atmosphere. Thermal modernization of energy-intensive buildings is, therefore, the first step to lowering low emissions by reducing the energy consumption. It is also extremely important to replace existing boilers with new ones with high efficiency or the use of gas sources, as well as the renewable energy sources.

The greatest potential to rationalize energy consumption and reduce pollutant emissions occur in the residential sector, which is one of the significant energy consumers in contemporary economies of developed countries. The aim is to estimate predicted energetic and ecological effects of activities that adapt existing residential buildings to the requirements for the thermal protection of buildings in Poland and presenting the possibilities and examples of the use of renewable energy sources.

\section{Improving the energy efficiency of buildings - process to reduce air pollutants}

Building stock of European Union covers about 200 million buildings, out of which 6 million are located in Poland. Realization and exploitation of buildings involves in European Union about $40 \%$ of total energy consumption, bat in Poland, this value is higher $[9,10]$. In accordance with the Polish National Energy Conservation Agency the energy consumption in Poland is at the level of around $120-300 \mathrm{kWh} /\left(\mathrm{m}^{2}\right.$ year $)$ while other European countries reach $50 \mathrm{kWh} /\left(\mathrm{m}^{2}\right.$ year $)$.

Among residential buildings, over 404000 were built before 1918. They represent $7.3 \%$ of the total number of inhabited buildings. The age structure of residential buildings located in Poland is presented in Fig. 3.

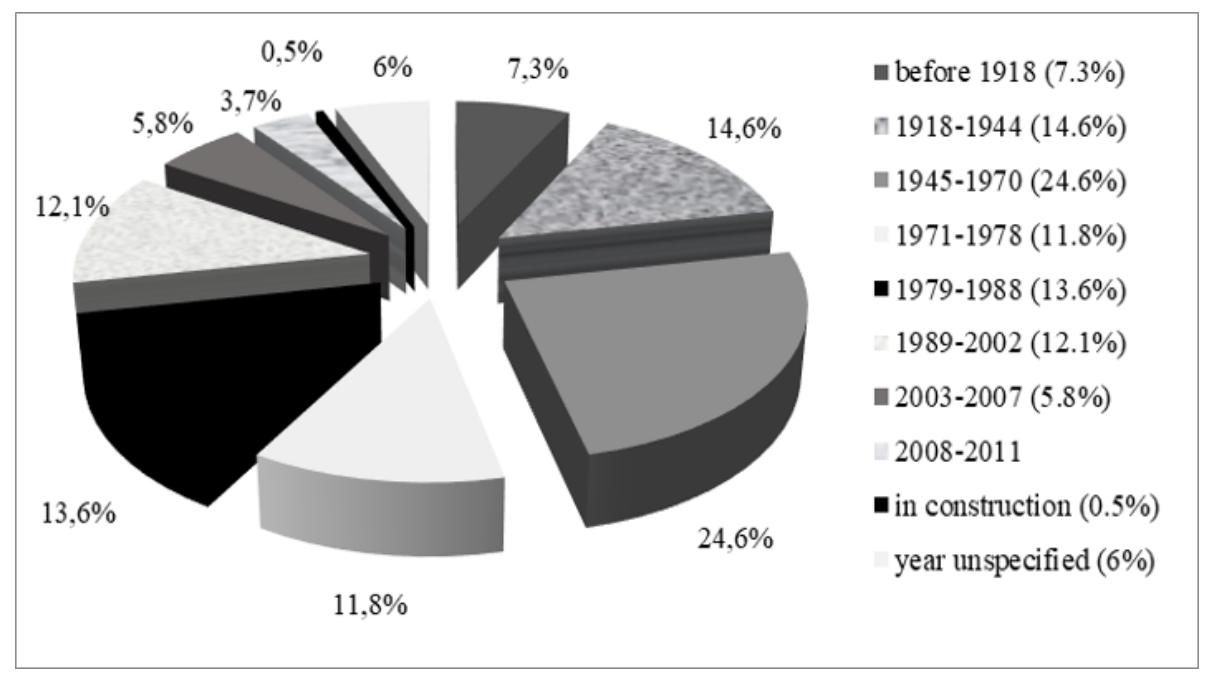

Fig. 3. The age structure of residential buildings in Poland $[10,11]$. 
There were about 1.2 million apartments, which accounted for $9.0 \%$ of total apartments in Poland [11]. About $85 \%$ of residential buildings are characterized by high energy intensity. Individual heating predominates in the heating of this buildings. Network heat consumed $41.7 \%$ of all. Approximately $67 \%$ of apartments had hot water heated locally, and $30 \%$ used district heating [10].

An analysis of the possibilities to reduce the energy demand for the heating of residential buildings which was exploited in Poland in 2011 to the value $70 \mathrm{kWh} /\left(\mathrm{m}^{2}\right.$ year) for multi-family buildings and $60 \mathrm{kWh} /\left(\mathrm{m}^{2}\right.$ year) for single-family buildings was conducted. The potential energy savings by reduction the energy demand for heating to accepted values is shown in Table $3[10,11]$.

Table 1. The potential energy savings by reduction the energy demand for heating

\begin{tabular}{|c|c|c|c|c|c|c|}
\hline \multirow{2}{*}{$\begin{array}{c}\text { The building } \\
\text { construction } \\
\text { period }\end{array}$} & \multicolumn{2}{|c|}{ Heat demand for heating } & \multicolumn{3}{c|}{ Reduce the energy demand for heating } \\
\cline { 2 - 7 } & \multicolumn{2}{|c|}{\begin{tabular}{c} 
single-family \\
\cline { 2 - 7 }
\end{tabular}} & multi-family & \multicolumn{2}{|c|}{ single-family } & \multicolumn{2}{c|}{ multi-family } \\
\hline before 1918 & 367.66 & 264.31 & 297.66 & 81.0 & 199.31 & 75.4 \\
\hline $1918-1944$ & 306.10 & 191.31 & 236.10 & 77.1 & 126.31 & 66.0 \\
\hline $1945-1970$ & 265.22 & 172.74 & 195.22 & 73.6 & 107.74 & 62.4 \\
\hline $1971-1988$ & 230.25 & 156.52 & 160.25 & 69.6 & 91.52 & 58.5 \\
\hline $1989-2010$ & 183.36 & 125.67 & 113.36 & 61.8 & 60.67 & 48.3 \\
\hline
\end{tabular}

Saving on energy demand for heating for the whole building structure was around $67 \%$.

Based on reducing the energy demand to heating of buildings the reduction of pollutant emissions to the atmosphere was estimated. Ecological effect of reduction the energy demand for the heating of residential buildings, which was exploited in Poland in 2011 to the accepted values is shown in Table 2 [1].

Table 2. Reduce of pollutants emissions

\begin{tabular}{|l|c|c|}
\hline \multicolumn{1}{|c|}{ Analyzed pollutants } & $\begin{array}{c}\text { Pollutants emission } \\
\text { resulting from the } \\
\text { apartments heating in 2011 }\end{array}$ & $\begin{array}{c}\text { Reduce of pollutants } \\
\text { emissions as a result of } \\
\text { reduced demand for energy }\end{array}$ \\
\cline { 2 - 3 } & thou. of tons & 41.40 \\
\hline Particulate matter $\mathrm{PM}_{2,5}$ & 61.348 & 70.02 \\
\hline Particulate matter $\mathrm{PM}_{10}$ & 103.756 & $3,3367,16$ \\
\hline Carbon dioxide $\left(\mathrm{CO}_{2}\right)$ & $49,440,568$ & $1,094.89$ \\
\hline Carbon monoxide $(\mathrm{CO})$ & $1,622.308$ & 147.92 \\
\hline Sulfur oxides $\left(\mathrm{SO}_{\mathrm{x}}\right)$ & 219.180 & 0.61 \\
\hline Nitrous oxide $\left(\mathrm{N}_{2} \mathrm{O}\right)$ & 0.906 & 45.56 \\
\hline Nitrogen oxides $\left(\mathrm{NO}{ }_{\mathrm{x}}\right)$ & 67.506 & 81.58 \\
\hline Methane $\left(\mathrm{CH}_{4}\right)$ & 120.873 & 0.34 \\
\hline Ammonia $\left(\mathrm{NH}_{3}\right)$ & 0.510 & 69.36 \\
\hline Non-methane volatile organic compounds & 102.769 & 91.04 \\
\hline Dioxins and furans $(\mathrm{g}$ i-TEQ) & 134.9 & 1.89 \\
\hline Hexachlorobenzene (HCB) & 2.8 & 0.00 \\
\hline Polychlorinated biphenyls (PCB) & 0.0004353 & 0.08 \\
\hline Polycyclic aromatic hydrocarbons (WWA) & 0.1230266 & \\
\hline
\end{tabular}


Reduction in energy demand for heating will reduce pollutants emissions, especially burdensome for the environment and the people, such as particulate matter and carbon dioxides. It has been estimated that the possibilities to reduce $\mathrm{CO}_{2}$ emissions, resulting from the exploitation of buildings up to 2030 year is $3,7 \mathrm{Gt}$ [12]. On the basis of the obtained data in Fig. 4 the potential reduction of $\mathrm{CO}_{2}$ emissions in various regions is presented [12].

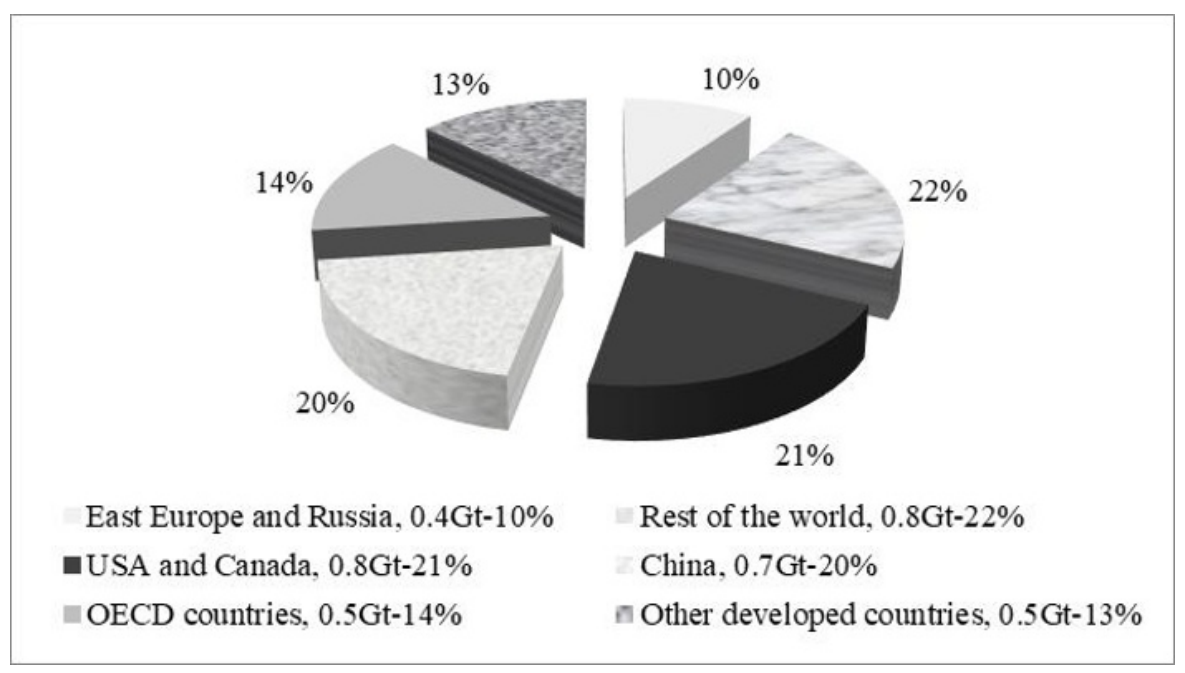

Fig. 4. The potential for reducing CO2 emissions in operation of buildings up to 2030 [12].

\section{Renewable energy sources as activities towards zero- emissivity}

Starting from 2021, all newly constructed buildings will be required to have very low energy consumption, covered mainly by the renewable energy resources. In recent years, special attention has been paid to zero emissivity in building construction. In the assumptions of the Polish National Program for the Development of Low-emission Economy adopted by the Council of Ministers in 2011, one of the main goals is the development of low-emission energy sources [13]. Four scenarios for the development of zero-emission economy in Poland in the 2050 perspective were developed [14]. The scenario which suggests a $73 \%$ increase in the share of renewable heat sources and the gradual withdrawal of coal energy seems to be the most beneficial. The energy potential of renewable energy sources in Poland is significant: wind energy - 36.0 PJ, hydro energy 43.0 PJ, energy from biomass - 895.0 PJ, geothermal energy - 1,512.0 PJ and solar energy - 1,340.0 PJ [15]. In 2017, Poland obtained 326,761.0 TJ from these sources, which accounts for a $14.1 \%$ share in final energy consumption [16]. Biomass has the largest share in renewable heat sources in Poland, but its combustion is a source of pollutant emissions to the atmosphere, especially suspended particulates and dioxins [1].

The example of using solar energy is the solar panel system in specialist hospital in Czestochowa. It is the one of largest solar collector installation in Poland (Fig. 5). Solar installation consists of 598 collectors with an area about $1500 \mathrm{~m}^{2}$. The structure is positioned on three fields located on the roof of the building and directly on the ground level. Solar exchanger technology based on three buffer tanks, hot water storage tank, plate heat exchangers.

The total installed capacity is about $1000 \mathrm{~kW}$. Average daily consumption of hot water by the hospital is about $53 \mathrm{~m}^{3}$. The collectors cover demand in $51.8 \%, 32.3 \%$ guarantee the 
economizers recovering heat from exhaust, cooperating with the existing 4 steam boilers gas-oil, which provide the remaining $15.9 \%$ of power. During sunny weather, the solar installation together with economizers can heat all the water needed for the hospital, with a minimum of sunlight reaching the efficiency of about $84 \%$.

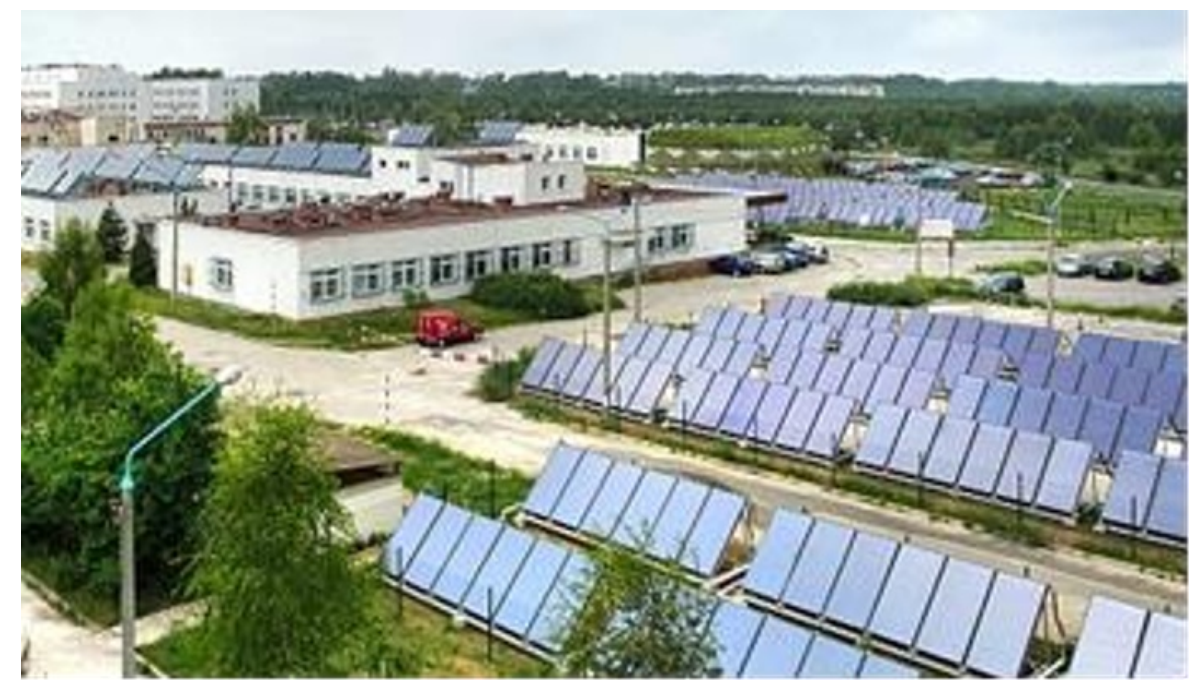

Fig. 5. The potential for reducing CO2 emissions in operation of buildings up to 2030 [12].

The energy-saving technology of economizers will significantly reduce the operating costs of the hospital in terms of fees for energy utilities, the facility can save up to $85000 \$$ a year. Installation of solar installations in hospitals is very popular now.

The next example is possibilities of using unconventional energy sources relying on low- and high-temperature geothermal waters for heating. On Polish territory, there are several Geothermal Plant i.a. Bańska Niżna, with water temperature of $60-100{ }^{\circ} \mathrm{C}$ (capacity - 4.5 MJ/s), Pyrzyce, with water temperature of approx. $60^{\circ} \mathrm{C}$ (capacity - $15 \mathrm{MJ} / \mathrm{s}$ ), Mszczonów, with water temperature of approx. $40^{\circ} \mathrm{C}$ (capacity $-7.3 \mathrm{MJ} / \mathrm{s}$ ), Uniejów, with water temperature of approx. $67^{\circ} \mathrm{C}$ (capacity - $2.6 \mathrm{MJ} / \mathrm{s}$ ) and Słomniki, with water temperature of approx. $17^{\circ} \mathrm{C}$ (capacity - $1 \mathrm{MJ} / \mathrm{s}$ ). The Słomniki Heat-Generating Plant is Poland's only plant using low-temperature heat as the lower source[17]. In the Silesian province, the largest technical potential of geothermal water exists in reservoirs located in the Miechów trough, in the areas of the Czestochowa and Zawiercie districts, as well as in the Cieszyn district.

One of the examples of the potential for utilizing low-temperature geothermal water for heat-generating purposes is a deep bore-hole in Poczesna (Czestochowa district) [17]. Pumped water volume flux is $24 \mathrm{~m}^{3} / \mathrm{h}, 40 \mathrm{~m}^{3} / \mathrm{h}, 50 \mathrm{~m}^{3} / \mathrm{h}$ and $80 \mathrm{~m}^{3} / \mathrm{h}$. Source power is $406 \mathrm{~kW}, 677 \mathrm{~kW}, 846 \mathrm{~kW}$ and $1353 \mathrm{~kW}$. For the low-temperature geothermal heatgenerating plant in the locality of Poczesna, the following facilities have been assumed to be connected: Library - $50 \mathrm{~kW}$, Office Building - $175 \mathrm{~kW}$, School - $320 \mathrm{~kW}$, Health Centre - 50 kW, Preschool - 105 kW, Police Station - 44 kW, Poczesna Fire Brigade - 25 $\mathrm{kW}$ and Church - $50 \mathrm{~kW}$. When heating only part of the above-mentioned facilities, a monovalent system with the heat pump as the only central heating system supply source could be used. In the event, where heating of all buildings is assumed, the thermal power of the geothermal water source under consideration would not be sufficient. An additional heat source could be provided by a gas boiler. 


\section{Conclusions}

To improve air quality, by 2030 year, the European Union plans to reduce energy consumption by $32.5 \%$, increase in the share of renewable sources in its final consumption up to $27 \%$ and reducing $\mathrm{CO}_{2}$ emissions by $40 \%$ compared to 1990 levels, and by 2050 even by $95 \%[17,18]$. Although Poland achieved a reduction of $30 \%$ in the emission of greenhouse gases, expressed as a carbon dioxide equivalent, in relation to the base year this, however air quality in Poland is still not at a satisfactory level [1]. The dominant cause of exceedances is low emissions from the fuels combustion in boilers and furnaces.

Rationalization of energy consumption in buildings through thermal modernization is the basis for reducing low emissions especially in the area where buildings with individual boiler rooms or stoves are located. Replacing exhausted heating devices with new and high efficiency, prohibition of using coal in particularly endangered areas, consistent enforcement of the ban on waste combustion, as well as increasing the share of renewable energy sources in its production will additionally significantly reduce the emission of dangerous substances into the atmosphere in particular particulate matter, carbon dioxide or benzo(a)pyrene and others.

Possibilities for energy savings in buildings, mainly residential ones, are estimated at $33-60 \%$ for improvement of thermal insulation of walls, $16-21 \%$ for modernization of ventilation system, $14-20 \%$ for improvement of thermal insulation of windows and $50-80 \%$ for modernization of hot water system with the use of renewable energy.

An analysis of the possibilities of reducing the energy consumption for heating of residential buildings and the emission of pollutants to the atmosphere generated during its production in relation to energy use in buildings clearly indicates the greatest potential for activities undertaken in the area of rooms heating. The calculations show that, as a result of adjusting the energy demand for residential heating to $60-70 \mathrm{kWh}\left(\mathrm{m}^{2} \mathrm{rok}\right)$, the demand for existing residential buildings can be reduced by an average of around $67 \%$ compared to 2011. Taking these activities will reduce the air pollutant emissions too.

Considering the fact that the heating demand for heating in Poland is about twice as high as in comparison with European standards, improvement of energy efficiency in this area may result in a reduction of national energy consumption by over $10 \%$. This saving would be accompanied by a decrease in particulate matter and $\mathrm{CO}^{2}$ emissions on a similar scale. It is estimated that due to the implementation of EU directives in this area, $\mathrm{CO}^{2}$ emissions by 28 million tons per year can be reduced.

Solid fuels, mainly poor quality coal and district heating, play a leading role in heating buildings. Solid fuels are the basic heating energy carrier for single-family houses, and network heat for multi-family buildings. The production of district heat takes place in about $75 \%$ also with the participation of coal. However, centralized production and application of filters has no negative impact on the environment. The third place among used energy carriers is natural gas. This more friendly for environment fuel is used in $10 \%$ of residential buildings. Natural gas is characterized by about $35 \%$ lower nitrogen oxide emissions and about $97 \%$ lower carbon monoxide emissions. Gas combustion does not properly emit particulate matter, sulphur dioxide and benzo (a) pyrene. Therefore, the solution to the problem of low emission in cities would be replacement coal boilers with gas boilers or connection of single-family houses to the network, but also no wood burning in open furnaces. In the perspective, the conventional power industry will not be able to meet growing energy needs, chiefly due to the conventional fuel sources being limited and rapidly exhausted. However, in the perspective the energy based on coal or gas will not be able to meet the growing energy needs, also due to the limited and rapid depletion of these sources. 
Renewable technologies are clean sources of energy and optimal use of these resources minimize environmental impacts and produce minimum secondary wastes. Solar radiation, geothermal water, wind and hydroelectricity are widely available renewable energy on Earth [20]. Supporting the development of renewable energy sources is one of the key elements of sustainable development, contributes to increasing the security of energy supply and economic development, as well as regional development and rural development. By reducing the emission of pollutants into the atmosphere, climate change is reduced, and the health condition of the society and the state of the natural environment are improved. The production of energy from renewable sources ensures positive environmental effects and at the same time contributes to the development of less developed regions.

\section{References}

1. Environment (Central Statistical Office, Warsaw, 2018)

2. B.R. Gurjar, L.T. Molina, C.S.P. Ojha (eds.), Air Pollution, Health and Environmental Impacts (CRC Press, New York, 2010)

3. The Eco Experts, https://blog.theecoexperts.co.uk/most-toxic-countries

4. R. Maas, P. Grennfelt (eds), Towards Cleaner Air, Scientific Assessment Report (Narayana Press, 2016)

5. WHO's Global Urban Ambient Air Quality Database (WHO, 2018)

6. Air quality in Europe, Report 2017 (EEA, 2017)

7. The state of the environment in Poland, Report 2018 (The Chief Inspectorate for Environmental Protection, 2018)

8. M. Holland, Cost-Benefit Analysis of Final Policy Scenario for the EU Clean Air Package (EMRC 2014)

9. Energy and environment. Statistical pocketbook 2018 (European Commission, 2018)

10. Energy consumption in households in 2015 (Central Statistical Office, Warsaw, 2017)

11. Apartments. National Census of Population and Apartments 2011 (Central Statistical Office, Warsaw, 2013)

12. Vattenfall's Climate Map (www.vattenfall.com/climatemap, 2007)

13. A. Węglarz, The new mission - to lower emissions (KSI, Warsaw 2014)

14. I. Pyka, K. Czaplicka-Kolarz (eds.) Scenarios for the development of zero-emission energy management in Poland in the perspective of 2050 (Central Mining Institute, 2010)

15. Energy Regulatory Office. https://www.ure.gov.pl

16. Energy from renewable sources in 2017 (Central Statistical Office, Warsaw, 2018)

17. A. Lis, P. Lis, R. Sekret, Possibilities of using geothermal water for heating buildings, L. Kurzak (eds.) Renewable energy in construction (WWZPCz, Czestochowa, 2009)

18. Directive 2018/844/EU of the European Parliament and of the Council of 30 May 2018 amending Directive 2010/31/EU on the energy performance of buildings and Directive 2012/27/EU on energy efficiency (2018)

19. Directive 2018/2001/EU of the European Parliament and of the Council of 11 December 2018 on the promotion of the use of energy from renewable sources (2018)

20. Renewables 2018, Global status report, (REN21, 2018) 